\title{
INVESTIGATION OF THE DIRECTION OF THE REACTIONS OF MERCAPTOACETIC ACID ESTERS WITH EPI- AND THIOEPICHLOROHYDRINS
}

\author{
K.Z.Guseinov, M.A.Mirzoeva* \\ Baku State University \\ *A.Guliyev Institute of Chemistry of Additives, NAS of Azerbaijan \\ gasimhuseynov@bsu.edu.az \\ Received 18.04.2020 \\ Accepted 22.06.2020
}

\begin{abstract}
The reactions of mercaptoacetic acid ethers with epi- and thio-epichlorohydrin in alkaline medium have been investigated. It was found that the reaction of mercaptoacetic acid esters with epichlorohydrin in the presence of an equimolar amount of sodium hydroxide simultaneously produces 2,3-epoxypropylalkoxycarbonylmethyl sulfides and 1-chlor-3-alkoxycarbonylmethylthiol-2-propanols. Under using sodium hydroxide is used as a catalyst, only 1-chlorine-3-alkoxycarbonylmethyltio-2-propa-nols are obtained the reaction of mercaptoacetic acid esters with epichlorohydrin. As a result of the interaction of mercaptoacetic acid esters with thioepichlorohydrin in the presence of equimolar amounts of sodium hydroxide, 2,3epitiopropylalkoxycarbonylmethyl sulfides are formed as the only products of the reaction.
\end{abstract}

Keywords: epichlorohydrin, thioepichlorohydrin, esters of mercaptoacetic acid, thiophenol sodium hydroxide.

doi.org/10.32737/0005-2531-2020-4-49-52

\section{Introduction}

The problem of developing the effective ashless additives for lubricating oils used in modern engines remains relevant today. The solution of this problem is connected with the creation of scientific bases for synthesis of additives with given properties.

There exists a great deal of information in the literature on the synthesis of various derivatives of thiophenols and mercaptans as anti-corrosion additives for lubricating oils. Among them - 2,3epoxypropyl(aryl) sulfides are of interest, containing both sulfide and epoxy groups, obtained by the reaction of epichlorohydrin with thiols:<smiles>[R]SCC1CO1</smiles>

This reaction proceeds both in the presence of the catalysts and without them. The direction of the reaction in the presence of catalysts depends on their amount and the ratio of the reacting components. In this case, various compounds can be obtained, since epichlorohydrin, being a bifunctional compound can react, on the one hand, with a halide group, and on the other, with the opening of the epoxy ring [1]. While the thiophenol reactions with epi- and thioepichlorohydrins have been sufficiently studied [1-4], the ester reactions of mercaptocarboxylic acid with these compounds have not been considered. The aim of the present work is to study the direction this reaction.

\section{Results and discussion}

Taking into account the fact previously revealed by us that in sulfides a substitution of the alkyl radical at the sulfur atom by the complex ether fragment $-\mathrm{CH}_{2} \mathrm{COOR}$ leads to a sharp increase of the anticorrosive activity of the compound, we were interested in study of the direction of the ester reactions of mercaptoacetic acid (EMAA) with epi- and thioepichlorohydrins under various conditions.

It has been established [5] that in the presence of equimolar quantity of the sodium hydroxide EMAA reaction with epichlorohydrin proceeds with formation of 2,3-epoxypropylalkoxycarbonylmethylsulfides and 1-chloro3-alkoxycarbonylmethylthio-2-propanols simultaneously: 


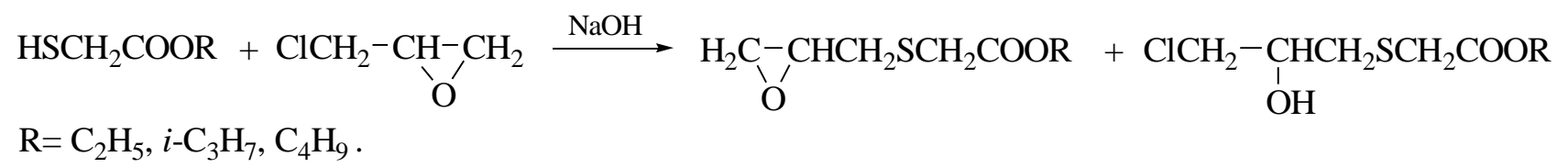

The yield of each of these products is $25-$ $30 \%$. The low yields of compounds have been apparently connected with partial hydrolysis of EMAA in the alkaline medium.

In the presence of catalytic quantities of the sodium hydroxide or triethylamine, EMAA acts like 2,5-dimethylthiophenol [5] and leads to the formation of only 1-chloro-3-alkoxycarbonylmethylthio-2-propanols with $70-90 \%$ yield.

The structure of the synthesized compounds has been studied by a method of PMR. The PMR spectra were recorded on spectrometers T-60 of firm "Varian" with working frequency $60 \mathrm{MHz}$ and firm "Tesla" with working frequency $80 \mathrm{MHz}$. Hexamethyldisiloxane (HMDS) and tetramethylsilane (TMS) were used as an internal standard, the solvent was carbon tetrachloride. The accuracy of measurement of chemical shifts is $0.05 \mathrm{ppm}$, scale $\delta$.

In the PMR spectrum of 2,3-epoxypropylisopropoxycarbonylmethyl sulfide a singlet from $\mathrm{SCH}_{2} \mathrm{COO}$-group is observed at $\delta=3.17 \mathrm{ppm}$.

The resonance signals of protons of fragment are appeared as doublet from $-\mathrm{HC}-\mathrm{CH}_{2} \mathrm{~S}-$ $\underset{\text { O }}{\mathrm{H}_{2} \mathrm{C}}-\mathrm{CHCH}_{2} \mathrm{~S}$ - and $-\mathrm{CH}^{\mathrm{C}}-\mathrm{CH}_{2}$ group with chemical shift $\delta=2.7 \mathrm{ppm}$ and from with chemical shift $\delta=2.6 \mathrm{ppm}$, the proton of methine group appears as a quintet at $\delta=3.0 \mathrm{ppm}$.

In the PMR spectrum of 1-chloro-3-isopropoxycarbonylmethylthio-2-propanol the resonance signals of protons of $\mathrm{Cl}-\mathrm{CH}_{2}-\mathrm{CH}(\mathrm{OH}) \mathrm{CH}_{2} \mathrm{~S}$ fragment are appeared as two doublets from methylene groups with chemical shifts $\delta_{\mathrm{a}}=2.8$ ppm and $\delta_{\mathrm{B}}=3.6 \mathrm{ppm}$, as a quintet from methine group at $\delta_{\mathrm{c}}=3.85 \mathrm{ppm}$ and a singlet from $\mathrm{OH}-$ group at $\delta=3.8 \mathrm{ppm}$. The resonance signal of protons of $-\mathrm{S}-\mathrm{CH}_{2}-\mathrm{COO}$-group are observed as a singlet at $\delta=3.23 \mathrm{ppm}$. The resonance signals of protons of $-\mathrm{CH}\left(\mathrm{CH}_{3}\right)_{2}$ in the PMR spectra of above-mentioned compounds are observed as a doublet of two methyl groups at $\delta=1.22 \mathrm{ppm}$ and sextet from methine group with chemical shift at $\delta=4.95 \mathrm{ppm}$.

The study of the reaction of compounds containing mercapto- group with sulfurous ana$\log$ of epichlorohydrin - thioepichlorohydrin is of particular interest. These reactions lead to the formation mainly of thiiranes - sulfurous ana$\operatorname{logs}$ of epoxy compounds.

A number of works has been devoted to the synthesis and investigation of thiiranes [68]. It has been shown that thiophenolate potassium reacts with tioepichlorohydrin to form a single reaction product of 2,3-epithiopropylphenylsulfide [9].

Earlier, a number of alkyl- and aryl-2,3epithiopropyl sulfides have been synthesized by the reaction of various alkanethiols and thiophenols with thioepichlorohydrin in the presence of an aqueous solution of the sodium hydroxide at $60^{\circ} \mathrm{C}[3]$.

We have studied the interaction of thioepichlorohydrin with EMAA in alkalin melium [10] and established that the single products of this reaction are 2,3-epithiopropylalkoxycarbonylmethyl sulfides:

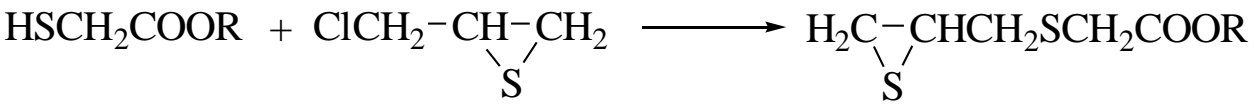

$$
\begin{aligned}
& \mathrm{R}=\mathrm{C}_{2} \mathrm{H}_{5}, \mathrm{C}_{3} \mathrm{H}_{7}, i-\mathrm{C}_{3} \mathrm{H}_{7}, \mathrm{C}_{4} \mathrm{H}_{9}, i-\mathrm{C}_{4} \mathrm{H}_{9}, \mathrm{C}_{5} \mathrm{H}_{11}, \mathrm{C}_{6} \mathrm{H}_{13} \text {. }
\end{aligned}
$$

It was known [1] that the oxygen atom of epoxy group is easily exchanged for a sulfur atom of thiourea with formation of thiirane cycle. It has been shown that as a result of the re- 
action of 2,3-epoxypropylethoxycarbonylmethyl sulfide with thiourea 2,3-epithiopropylethoxy- carbonylmethyl sulfide is formed:<smiles>CCOC(=O)CSCC1CS1</smiles>

In the IR-spectrum of 2,3-epithiopropylalkoxycarbonylmethyl sulfides there are absorption bands in the field of $1720-1728 \mathrm{~cm}^{-1}$, characteristic for $\mathrm{CO}$ group, and also bands at 625 and $670-673 \mathrm{~cm}^{-1}$, indicating the presence of thiirane cycle $[11,12]$.

In the NMR spectrum of 2,3-epithiopropylpropoxycarbonylmethyl sulfide the chemical shifts in the field of 2.17-2.92 ppm characterize the protons of propylene sulfide residue. Along with this, there are signals with chemical shifts 0.97 (protons of $\mathrm{CH}_{3}$ group), 1.58 (protons of $\mathrm{CH}_{2}$-group, adjacent to $\mathrm{CH}_{3}$ ), 3.98 (protons of $-\mathrm{CH}_{2}-\mathrm{O}$-group) and 3.17 (protons of $-\mathrm{CO}-\mathrm{CH}_{2}-$ group) ppm [13].

It follows from consideration of the abovementioned material that in the reactions with haloid-containing compounds in the alkaline medium, EMAA acts like thiophenols, excepting EMAA reaction with epichlorohydrin in the presence of an equimolar quantity of the sodium hydroxide, when along with 2,3-epithiopropylalkoxycarbonylmethyl sulfides rather 1-bis (alkoxycarbonyltio)-2-propanols, but 1-chlorine-3-alkoxycarbonylmethylthio2-propanols are formed.

There have been investigated the anticorrosive and anti-wear properties of the synthesized compounds in the mineral oil DS-11 at the end of $0.5-1 \%$. The anticorrosive properties were determined on apparatus DK-2 on a method NAMI (GOST 20502-75 variant 2). The results of tests showed that the obtained 2,3epoxypropylalkoxycarbonylmethyl sulfides and 1-chloro-3-alkoxycarbonylmethylthio-2-propanols possess high anticorrosive properties and at concentration $0.5 \%$ decrease the corrosion of lead plates from $180 \mathrm{gm}^{-2} \mathrm{~h}^{-1}$ to 1.3 and $2.4 \mathrm{gm}^{-2} \mathrm{~h}^{-1}$. The anti-wear properties of the compounds were studied in the oil solution DS-11 on a friction machine CHSHM-3.3 (GOST 9490-75) at an axial load of $392 \mathrm{~N}$ and the experiment duration for $60 \mathrm{~min}$. The test results showed that these compounds at the same concentration decrease the diameter of the wear spot from 1.01 $\mathrm{mm}$ to $0.46-0.56 \mathrm{~mm}$.

It should be noted that the obtained alkoxycarbonylmethylglycidyl- and hydroxy-3chloropropylalkoxycarbonylmethyl sulfides can also be used as synthons for further synthesis and study of new classes of compounds.

\section{Conclusions}

1. It has been established that in the presence of an equimolar quantity of the sodium hydroxide, the reaction of mercaptoacetic acid esters with epichlorohydrin proceeds with the formation of 2,3-epoxypropylalkoxycarbonylmethyl sulfides and 1-chloro-3-alkoxycarbonylmethylthio-2-propanols simultaneously.

2. In the presence of catalytic quantities of the sodium hydroxide or triethylamine the esters of mercaptoacetic acid acts like thiophenols and leads to the formation of 1-chloro-3-alkoxycarbonylmethylthio-2-propanols with 70-90\% yield.

3 . The reaction of mercaptoacetic acid esters with thioepichlorohydrin proceeds with the conservation of thiirane cycle and formation of only reaction products - 2,3-epithiopropylalkoxycarbonylmethyl sulfides. The latter ones are also formed as a result of the reaction of 2,3epoxypropylalkoxycarbonylmethyl sulfides with thiourea.

4. The synthesized compounds have been investigated as additives for lubricating oils. It has been established that 2,3-epoxypropylalkoxycarbonylmethyl sulfides possess high anticorrosive, antimicrobial and anti-wear properties.

\section{References}

1. Paken A.M. Epoksidniye soyedineniya i epoksidniye smoly. L.: Goskhimizdat, 1962. 964 s. 
2. Kuliev A.M., Movsumzade M., Mamedov F.N. Reaktsiya epikhlorgidrina s nekotorymi alkilfenolami i aromaticheskimi tiolami. Azerb. Chem. Journ. 1966. № 6. S. 20-22.

3. Byashimov K. Sintez, issledovaniye stroyeniya, reaktsionnoy sposobnosti i oblastey primeneniya tioglitsidilsulfidov. Diss. kand. khim. nauk, Baku: IKHP AN Azerb. SSR. 1974. 135 s.

4. Kuliev A.M., Guseynov K.Z. Sintez i nekotoriye prevrasheniya 2,5-diketiltiofenolov. V sb.: Additives for lubricatinf oils. Baku: Izd-vo AN Azerb.SSR. 1967. S. 44-47.

5. Kuliev A.M., Guseynov K.Z., Mamedov F.N., Mirzoyeva M.A. Reaktsii efirov tioglikolevoy kisloty s akrilonitrilom i epikhlorgidrinom. Dokl. AN Az.SSR. 1976. T. 32. № 6. S. 27-31.

6. Farzaliev V.M. Nauchniye osnovy razrabotki effektivnykh serosoderzhashikh prisadok k smazochnym maslam. Diss. dokt. khim. nauk. Baku: IKHP AN Azerb. SSR. 1986. S. 428.
7. Fokin A.V., Kolomiets A.F. Khimiya tiranov. M.: Nauka, 1978. 344 s.

8. Sander M., Chem.Soo. Rev. 1966. V. 6. P. 297-301.

9. Arbuzov B.A., Nuretdinova O.N., Nikonova L.Z. Reaktsiya tioepikhlorgidrina s tiofenolyatom kaliya. Izv.AN SSSR. Ser.khim. 1969. S. 167-172.

10. Kuliev A.M, Byashimov K., Guseynov K.Z., Mamedov F.N. Sintez i issledovaniye karboalkoksimetiltioglitsidilsulfidov. J. Org. Chem. 1972. T. 8. V. 11. S. 2256-2258.

11. Nakanisi K. Infrakrasniye spektry i stroyeniye organicheskikh soyedineniy. M.: Mir, 1965. 216 s.

12. Scott D.W., Waddington G. Thioacyclopropane (Ethylene Sulfide): Infrared Spectrum, Vapor Pressure and Some Thermodynamic Properties. J. Am. Chem. Soc. 1952. V. 74. P. 2795-2800.

13. Mushert J.X., Gordon R.G. NMR Spectrum of Propylen Sulfide. J. Chem. Phys. 1962. V. 36. P. 3097-3098.

\title{
MERKAPTOSIRKO TURŞUSU EFIRLORININ EPI- VӘ TIOEPIXLORHIDRINLERLə REAKSIYALARININ TODQIQQi
}

\author{
Q.Z.Hüseynov, M.Ә.Mirzəyeva
}

Qələvi mühitdə merkaptosirkə turşusu efirlərinin epi- və tioepixlorhidrinlərlə reaksiyaları öyrənilmişdir. Müəyyən olunmuşdur ki, ekvimolyar miqdarda natrium hidroksid iştirakı ilə merkaptosirkə turşusu efirlərinin epixlorhidrinlə reaksiyasından eyni zamanda 2,3- epoksipropilalkoksikarbonilmetil sulfidlər və 1- xlor- 3-alkoksikarbonilmetiltio-2propanollar əmələ gəlir. Natrium hidroksiddən katalizator kimi istifadə etdikdə merkaptosirkəturşusu efirlərinin epixlorhidrinlə reaksiyasından yalnız 1-xlor-3-alkoksikarbonilmetiltio-2-propanollar alınır. Ekvimolyar miqdarda natrium hidroksid iştirakı ilə merkaptosirkəturşusu efirlərinin tioepixlorhidrinlə qarşılıqlı təsiri nəticəsində reaksiyanın yeganə məhsulu kimi 2,3- epitiopropilalkoksikarbonilmetilsulfidlər əmələ gəlir.

Açar sözlor: epixlorhidrin, tioepixlorhidrin, merkaptosirka turşunun efirlari, tiofenol, natrium hidroksid

\section{ИССЛЕДОВАНИЕ НАПРАВЛЕНИЯ РЕАКЦИИ ЭФИРОВ МЕРКАПТОУКСУСНОЙ КИСЛОТЫ С ЭПИ- И ТИОЭПИХЛОРГИДРИНАМИ}

\section{К.З.Гусейнов, М.А.Мирзоева}

Изучены реакции эфиров меркаптоуксусной кислоты с эпи- и тиоэпихлоргидринами в щелочной среде. Установлено, что в присутствии эквимолярного количества едкого натра реакция эфиров меркаптоуксусной кислоты с эпихлоргидрином протекает с образованием смеси 2,3-эпоксипропилалкокенкарбонилсульфидов и 1хлор-3-алкоксикарбонилметилтио-2-пропанолов. В присутствии каталитических количеств едкого натра реакции эфиров меркаптоуксусной кислоты с эпихлоргидрином приводят к образованию лишь 1-хлор-3алкоксикарбонилметилтио-2-пропанолов. В присутствии эквимолярного количества едкого натра эфиры меркаптоуксусной кислоты реагируют с тиоэпихлоргидрином с образованием в качестве продуктов реакции только 2,3-эпитиопропилалкоксикарбонил-метилсульфидов.

Ключевье слова: эпихлоргидрин, тиоэпихлордидрин, эфиры меркаптоуксусной кислоть, тиофенол, гидроксид натирия. 